В. В. Тишин

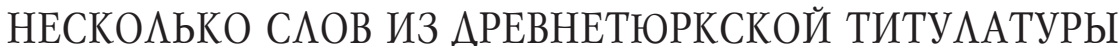 (К ВОПРОСУ О ФИНА ЬННОМ -N В ИМЕННЫХ ОСНОВАХ В ОАНОМ ИЗ АРЕВНЕТЮРКСКИХ НАРЕЧИЙ)
}

В статье обращено внимание на несколько слов, зарегистрированных в известном по китайским источникам перечне титулатуры, бытовавшей в среде племени тюрк (кит. my-uзюэ 突厥). Четыре реконструируемых слова, *tar(a)ban, *(h)alan, *ayan, *börin, три из которых имеют очевидные аналогии в ряде тюркских языков, демонстрируют наличие нехарактерного финального $-n$, который не поддается надежному объяснению. Автор рассчитывает привлечь специальное внимание лингвистов к данному материалу.

Ключевые слова: древние тюрки, Тюркский каганат, ономастика, титулатура, тюркские языки, среднекитайский язык, фонетическая реконструкция.

\section{V. Tishin \\ SEVERAL WORDS FROM OLD TURKIC TITULATURE (ON THE PROBLEM OF THE FINAL -N IN THE NOMINAL STEMS IN ONE OF THE OLD TURKIC DIALECTS)}

The article draws attention to a few words attested in the list of titulature known from Chinese written sources, which existed among the Türk tribe (Chinese: Tü-jué 突厥). Four reconstructed words, are *tar(a)ban, *(h)alan, *ayan, *börin, three of which have obvious analogies in a number of Turkic languages, demonstrate the presence of an inexplicable final $-n$, which cannot be reliably explained. The author of the article expects to attract a special attention of linguists to the material presented.

Keywords: Early Turks, Türkic Qaghanate, onomastics, titulature, Turkic languages, Middle Chinese, phonetic reconstruction.

Dанняя история тюркоязычных народов до появления на исторической арене племенной группировки тӥрк, с которой связаны первые известные науке тюркоязычные письменные памятники тюркских языков и от которой они в итоге получили свое название, известна плохо. Бесспорно, что основной массив сведений содержится в китайских источниках, именующие названную общность ту-изюэ 突厥, первые сведения о которой относятся к середине VI в., появляясь в официальных династийных историях - «Чжоу шу» 周書 ([Официальная] история [династии] Северное Чжоу, завершена в 629 г.), «Бэй Ци шу» 北齊史 ([Официальная] история [династии] Северное Ци, завершена в 638 г.), «Суй шу» 隋書 ([Официальная] история [династии] Суй, составлена в 629-636 гг,, окончательно завершена в 641-656 гг.), сведенных затем, будучи несколько отредактированы, в «Бэй ши» 北史 (История северных [династий], написана в 643-659 г.). Впоследствии эти сведения

ТИШИН Владимир Владимирович - кандидат исторических наук, старший научный сотрудник отдела истории и культуры Центральной Азии Федерального государственного бюджетного учреждения науки «Институт монголоведения, буддологии и тибетологии СО РАН» (Улан-Удэ, Россия). E-mail: tihij-511@mail.ru. 
о раннем периоде взаимоотношений тюрков с китайскими царствами, дополненные сведениями о последующих эпохах, были в том или ином виде перенесены в другие источники - танские династийные истории и различного рода сочинения энциклопедического характера [I].

К эпохе династии Тан 唐 (618-907) относится появление оригинального сочинения, принадлежащего только зачинающемуся тогда энциклопедическому жанру, «Тун дянь» 通典 (Общие установления), составленного в 801 г. Ду Ю 杜佑. Это наиболее ранний источник по истории тюрков, созданный в собственно танскую эпоху. $\Phi$. Хирт указал в качестве задействованных здесь источников упомянутые выше сочинения «Чжу фань фэн-су цзи» 诸蕃風俗記 и «Ту-цзюэ со чу фэн-су ши» 突厥所出 風俗事 под измененным названием «Ту-цзюэ бэнь мо цзи» 突厥本末記 (Основные и второстепенные записки о тюрках) [Hirth 1896: 228].

Именно здесь в цзюане (卷, т. е. главе) 197 впервые появляется фрагмент, содержащий оригинальную информацию о тюркской титулатуре, введенный в общее повествование о тюрках, коррелирующее с текстами ранних династийных историй. Речь идет не совсем о титулах, поскольку здесь зарегистрированы довольно разные по своей природе слова, в т. ч. и эпитеты, например связанные с личными качествами или какими-то бытовыми функциями [Кубатин 2016: 64].

Позже эти же сведения, но в несколько иной редакции появляются еще в двух источниках, относящихся уже к эпохе династии Сун 宋 (960-1270). Это, в сущности, компилятивные работы, однако отличающиеся тем, что содержат сведения из очень широкого круга ранних источников, которые были тщательно отредактированы.

В первую очередь, это зависимая от «Тун дянь» 通典 энциклопедия «Цэ-фу юань-гуй» 冊府元龜 (Изначальная черепаха императорской библиотеки), написанная в 1005-1013 гг. Ван Цинь-жо 王钦若, которая также в цз. 962 содержит отмеченный выше фрагмент. Второй источник - это историко-географический труд «Тай-пин хуань-юй цзи» 太平睘宇記 (Описание мира в период Тай-пин), составленный в 976-983 гг. Юэ Ши 樂史, где интересующий нас фрагмент помещен в ц3. 194.

Раздел о титулатуре уже давно привлекал исследователей и в той или иной степени комментировался [Visdelou 1779: 126; Klaproth 1827: 384-388; Hirth 1899: 139 (Anm. 1); Parker 1924: 131-132; Stein 1941: 420-430; Цэнь Чжун-мянь 1958: 528-529 (Тун дянь, 通典), 577-578 (Тай-пин хуань-юй цзи, 太平睘宇記); Liu MauTsai 1958: bd. I, s. 9, 498-499 (Anm. 49) (Тун дянь, 通典); Лю Маоцай 2002: 16-17; Drompp 1991: 96, 110 (note 25), 98, 111 (note 33); Зуев 1998: 154-155; 2002, 280; Taşağ1l 2003: 96-97 (Тун дянь, 通典), 114 (Цэ-фу юань-гуй, 冊府元匡); Қазақстан тарихы 2006: 122, 137-140 (58 түсін.); др.]. На русский язык перевод выполнялся, насколько нам известно, только Ю. А. Зуевым и дважды публиковался, с некоторыми отличиями в комментариях. Мы не можем останавливаться здесь на всем тексте [II], но хотели бы обратить внимание на формы нескольких употребляемых здесь титулов (гуань 官).

Ниже мы даем переводы отрывков из текстов и комментарий к ним. Предлагаемые переводы являются буквальными и не подвержены никакой литературной обработке, что, по нашему мнению, наиболее четко передает все особенности оригинального текста. Несмотря на видимую грубость текста, богатство русского языка вполне позволяет сохранять синтаксис и максимально придерживаться грамматических особенностей оригинала.

1) «Тучный и крупный кто, [того] называют да-ло-бянь 大羅便; да-ло-бянь 大羅便 [это] сосуд для вина (изюй-цฺи 酒器) также».

да-ло-бянь 大羅便: 
П. А. Будберг, оставляя за иероглифом бянь 便 синтаксическую роль, предложил видеть в сочетании да-ло 大羅 искаженную передачу оригинального звучания, позже получившего форму кит. бо-ло 匡羅 'drinking vessel', подобно тому как посредством кит. mу-мэнь 土門 < *tumïn передано оригинальное *bumїn. Сочетание бо-ло 匡羅 передает *bala, иранское заимствование, ср. греч. фіó $\lambda$ [Boodberg 1979: 134-135]. Ученый, отмечая, что чаша и меч являются неотъемлемым атрибутом кочевнического воина со скифских времен, делает отсылку к повествованию китайских источников о сюн-ну 匈奴 следующего содержания: «Кто на сражении отрубит голову неприятелю, тот получает в награду кубок вина, и ему же предоставляется все полученное в добычу» [Бичурин 1950: 50]; или «Тот, кто в сражении отрубит голову неприятелю или возьмет его в плен, жалуется одним кубком вина, ему же отдают захваченную добычу...» [Материалы... 1968: 41].

Хань Жу-линь стремится найти параллели с монгольским названием водки tarasu/n [Stein 1941: 421; Drompp 1991: 98, 111 (note 33); Зуев 1998: 155; 2002: 281].

Эти этимологии сложно принять, ввиду того что слово да-ло-бянь 大羅便 (пиньин. dà-luó-biàn < ран. ср.-кит. *da'/dajh-la-bhian ${ }^{h}$, позд.-ср.-кит. *tha 'thaj'-laphjian' [Pulleyblank 1991: 69, 203, 37]) фиксируется полностью как личное, дотронное имя тюркского удельного кагана - А-бо 阿波 (581-587).

Ю. А. Зуев приводит также в сравнение хот.-сак., иран. tcarba, согд. crp 'жирный' [1998: 155]. См.: хот.-сак. tcārba 'fat', согд. crp [čarp] id., н.-перс. čarb 'mild' и др. [Bailey 1979: 140]

Х. И. Эркоч предлагает сопоставить с зафиксированным у Махмӯда ал-Ка̄шгарӣ tolu تلو [tlw] в сочетании tolu id iş 'dolu kap' [Erkoç 2015: 47-48 (dipnot 85); 2016: 48 (dipnot 10)].

Предложенная в работе Ю. А. Зуева идентификация семантически наиболее соответствует известному значению, однако специального обоснования заслуживает соотнесение инициального в хот.-сак. $t c$ - [ts] и отраженного в среднекитайских звучаниях *d-, *th- $(<* t-/ * d-)$ [Kasai Yukiyo 2012: 125 (tab. II.3); 2014: 70 (tab. I.3)].

Учитывая трехэлементный характер транскрипции да-ло-бянь 大羅便, второй иероглиф следует трактовать как передачу слога (ср.: [Kasai Yukiyo 2012: 92 (Anm. 39), 116, 131-132 (tab. III.1); 2014: 84 (tab. III.1), 109-110, 128]). В этом случае мы должны восстанавливать что-то близкое к *taraban, хотя это необязательно.

2) «Называют лошадь (ма 馬) названием хэ-лань 賀蘭, потому имеются хэ-лань $c y-н u$ 賀蘭蘇尼 и иююэ $c y-н и$ 阙蘇尼, кто возглавляет войско, того этот чин (чжан бин чжи гуань 掌兵之官) тоже».

$x \ni-л а н b$ 賀蘭:

У Ю. Клапрота передано как kholan [Klaproth 1827: 384-385], у Э. Х. Паркера Ghoran [Parker 1924: 132]. Вероятно, пиньин. hè-lán < ран. ср.-кит. * ja -lan, позд.cp.-кит. *xha'-lan [Pulleyblank 1991: 123, 182], что-то вроде др.-тюрк. *(h)alan, обозначающее пегую лошадь [Stein 1941: 422-423; Зуев 1998: 156; 2002: 282-283; Қазақстан тарихы 2006: 122, 139 (58 түсін.)]. Предполагаемый инициальный $h$ - не обязателен, но если он и был, то, вероятно, этот спорадически регистрирующийся в других древнетюркских словах звук имел, по-видимому, скорее протетический, чем этимологический характер [Róna-Tas 2016: 73; Erdal 2016: 176-177]. Cp.: a:la "lit. 'parti-coloured, dappled, mottled, spotted, blotchy'; hence metaph. 'hypocritical, treacherous', and the like” [Clauson 1972: 126], 'пегий, в яблоках' [Древнетюркский словарь 1969: 32]. Здесь обращает на себя внимание нехарактерный конечный элемент $-n$.

В «Этимологическом словаре...» Э. В. Севортяна отмечается основное значение ala $\sim$ a:la 'пестрый', но отмечается также возможность существования глагольной 
формы *ala-, вычленяемой в ст.-осм. Alan alar 'разноцветный', 'пестрый', 'свет', 'рассвет', тур. диал. alar sabah 'рассвет', alaz alaz 'пестрые', 'разноцветные' [Севортян 1974: 129].

Для $c y$-ни 蘇尼 реконструкция была предложена П. Пельо, восстанавливавшего здесь * swarna suvarna [Pelliot 1934: 72-73 (note 3)]. По мнению Ю. А. Зуева, здесь $c y$-ни 蘇尼, возможно, отражает что-то вроде тюрк. *sü̈i ‘копье' [1998: 156; 2002: 284]. В китайских источниках под 584 г. упоминается племя (бу 部) с таким названием [Liu Mau-Tsai 1958: 67; Taşağıl 2003: 121, 156; Ecsedy 1968: 135, 164 (note 50)]. Позже известно также название племени (бу-ло 部落) $c y$-ни-ии 蘇尼失, предводителем которого был Ша-бо-ло 沙鉢羅 $(<*$ * isvara) шад, или же Су-ни-ши 蘇尼失, дядя Се-ли 頡利 кагана. В «Тан хуэй яо» 唐會要 сообщается следующее: «В 4 г. (630), во 2-ю луну, Ли Цзин, напав, разбил туцзюэ в Иньшане. Сйели убежал, с помощью Шаболо учредил аймак Суниши» [Кюнер 1961: 186]. В танских историях сообщается, что под его руководством находилось 50 тыс. семей-шатров [Parker 1901: 242; Liu Mau-Tsai 1958: 198, 266; Лю Маоцай 2002: 95; Taşağ1l 1999: 52; Қазақстан тарихы 2006: 166]. В иңюэ су-ни 烕蘇尼 первое слово - kül, известное в древнетюркской титулатуре [Clauson 1972: 715]. Ср. у Э. Х. Паркера köl-suni [Parker 1924: 132].

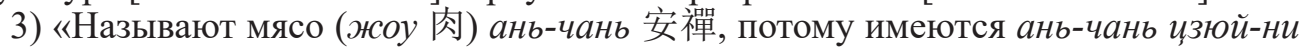
安禪具泥; заведует семейными делами (чжан иззя ши 掌家事), [что] подобно государственному чину чин (2о-гуань 國官)»

$a H b-4 a H b$ 安禪:

Уже К. Видлу написал “l'An-tchen, ou Ghan-tchen” [Visdelou 1779: 126], имея в виду, видимо, возможность взаимозаменяемости иероглифов ань 安 и жань 然, выступающих в тождественном значении в некоторых грамматических конструкциях. У Ю. Клапрота achan, сопоставляемое с ach اش اشق اشق اش Э. Х. Паркера andjan и далее, соответственно, andjan küni [Parker 1924: 131-132]. В древнетюркскую эпоху мясо обозначалось словом ӓt, которое никак не может быть здесь [Stein 1941: 424; Қазақстан тарихы 2006: 122, 140 (58 түсін.)].

Ю. А. Зуев, предлагая исправить иероглиф жоу 肉 ‘мясо' на нэй 內 'императорский двор', сближает ань-чань 安禪 с перс. hanedan / handan, т. е. хандан «фамильный дом», «династия», а ань-чань изэюй-ни 安禪具泥 восстанавливает как *handanküni в значении «род ханского двора» [1998: 158; 2002: 286-287].

Трактовка Ю. А. Зуева обнаруживает две проблемы - обоснование самой реконструкции и объяснение новоперсидского слова в древнетюркском языке. Ср.: ань-чань иззюй-ни 安禪具泥, пиньин. ān-chán jù-ní ран. ср.-кит. *?an-dzian guə-ncj, позд. ср.-кит. *?an-shian khyə"niaj [Pulleyblank 1991: 24, 48, 165, 223] < *an-(h)an k/ göni/ä.

По-видимому, речь идет о слове, близком к *aך 'дичь', 'дикие звери' (*‘слежка, наблюдение, подстерегание' > 'объект слежки' > 'дичь'); ср. глагольную основу

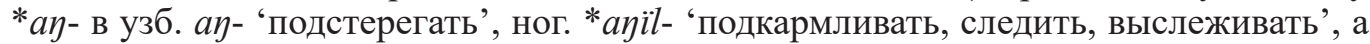
также общеалтайские параллели в письм.-монг. aך 'зверь, дикое животное, дичь; охота' (возможно, тюркизм) и эвенк. ауаn 'огороженное для оленей место', восходящее, вероятно, однако, к омонимичной гетерогенной основе ауа- 'рыть' [Сравнительно-историческая грамматика 2001: 152, 417]. B EDAL в одну группу объединены основы пратунг.-манчж. *aya- 'wild game (дикий зверь, дичь)', 'mountain ram (горный баран)', ‘to graze (of deer) (пастись (об оленях))', 'enclosure for deer (загон для оленей)', прамонг. *(h)оүипи 'male mountain antelope (самец горной антилопы)', пратюрк. * ‘̆ 'wild game (дикий зверь)', возводимые к праалт. *ӑүu 'wild game' [Starostin, Dybo, Mudrak 2003: 306].

Вероятно, в ань-чань 安禪 следует восстанавливать что-то близкое к *ajan. 
Второе слово может быть формально сопоставлено только с др.-тюрк. küni 'jealousy, jealousy; (hence? metaph.) a co-wife' [Clauson 1972: 727]. Может быть, действительно kün 'люди'?

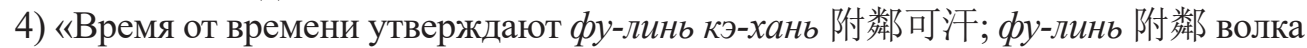
название есть; получает [кто его, тот] за его пристрастия убивать [так] называется».

$ф y-л и н ь$ 附鄰:

В данном случае $\phi y$-линь 附鄰, пиньин. fü-lín < paн. ср.-кит. *buə-lin, позд. ср.кит. *fhjyə"/fhuə"-lin [Pulleyblank 1991: 101, 194], передача формы типа *börin [Marquart 1898: 41 (Anm. 1), 110-111; Stein 1941: 424-425; Pritsak 1955: 53; Зуев 1998: 157-158; 2002: 287-288]. Ср. также название каганской гвардии фу-ли 附離 [Kasai Yukiyo, 2012: 89 (Anm. 25); 2014: 123], а также в личной ономастике формы Бу-ли 步 離 каган, Бу-ли 步利 шад [Liu Mau-Tsai, 1958: 798 (Index); Taşağıl 2003: 193 (Dizin)], передающие др.-тюрк. *böri ‘волк’ [Pritsak 1955: 53].

Для тюркского слова *böri 'волк' иногда приводятся иранские сопоставления (сак. birgga, осет. birceg), где вызывает проблемы, прежде всего, трансформация иранского - $i$ - в тюркский -ӧ- и утрата финального -g [Doerfer 1965: 333-334; Севортян 1978: 230-221; Сравнительно-историческая грамматика 2001: 159-160].

Таким образом, четыре приведенных реконструированных слова, *tar(a)ban, *(h)alan, *ayan, *börin, - по крайней мере, для трех из которых могут быть отмечены явные аналогии в тюркских языках, в т. ч. в древнетюркских памятниках, демонстрируют наличие финального элемента $-n$, не зарегистрированного ни в одном из случаев касательно гомогенных форм. Если, по крайней мере, в ситуации с *(h)alan и *ayan на основе сравнительного материала можно допустить, что они представляют собой отглагольные производные, то для *börin это затруднительно. С определенной оговоркой можно было бы предположить здесь наличие показателя множественности $+(A) n$ [Erdal 1991: 91-92], но в этом случае пришлось бы объяснять употребление других перечисляемых слов в китайском источнике в единственном числе какими-то случайными факторами.

А. Рона-Таш, реконструируя пратюркские формы показателей родительного падежа *-n, винительного *-nVG, дательного *-nKA и инструментального *-n $V n$, выдвигает предположение о существовании в пратюркском и, возможно, отчасти в древнетюркском языке у именных основ финального элемента - $n$ [Róna-Tas 1998: 73]. М. Эрдал возразил венгерскому исследователю: “There is, however, no way to reduce the nominal and the pronominal accusative suffixes to any common source by any sound laws known to have held for that stage of the language, and there is no evidence whatsoever that the dative and the instrumental suffixes ever started with an $/ \mathrm{n} /$. So the genitive suffix remains by itself, and 'oblique $-n$ ' remains a purely pronominal feature (found however, also with the collective suffix $+(A) g U$ in Orkhon Turkic, and also the possessive suffixes) as far as Turkic is concerned. While Turkic had an oblique pronominal $+n+$, Mongolic nominal vowel stems had a nominative $+n$ denoting specificity" [Erdal 2004: 168-169 (note 287)].

Вопрос о существовании финального - $n$ в монгольских именных основах пока еще не может быть решен однозначно [Janhunen 2003: 10]. Как отмечал еще Б. Я. Владимирцов, в старописьменных монгольских памятниках конечный $-n$ встречается более регулярно, но в тех же словах в новописьменных памятниках чаще опускается, сохраняясь, однако, в ряде случаев при аффиксации. Предполагается, что в некоторых словах он появился под влиянием аналогий, но в некоторых, повидимому, имел этимологический характер (какой-то аффикс?). Эти случаи трудно разграничить [1929: 356-357]. 
Мы не беремся однозначно высказываться касательно природы данного элемента в отмеченных выше древнетюркских словах. Однако, к высказанным выше предположениям о том, как может решаться эта проблема, возможно, следует добавить вариант, объясняющий появление данных слов в китайском через монголоязычного информатора (жоу-жань 柔然?).

Все эти слова уже попадали в поле зрения исследователей, но, насколько нам известно, специально подобные формы не выделялись для рассмотрения, учитывая дискуссионность ряда реконструкций. Настоящей работой нам бы хотелось, прежде всего, привлечь внимание лингвистов к данной проблеме.

Работа выполнена при финансовой поддержке гранта Правительства Российской Федерации 14.W03.31.0016 «Динамика народов и империй в истории Внутренней Азии».

\section{Примечания}

I. Подробную характеристику китайских источников о тюрках см., напр.: [Liu Mau-Tsai 1958: 475-483; Taşağıl 2003: 2-5].

II. В настоящее время готовится к публикации выполненный нами комментированный перевод.

\section{Иитература}

Бичурин Н. Я. [Иакинф]. Собрание сведений о народах, обитавших в Средней Азии в древние времена Т. I / Н. Я. Бичурин [Иакинф]; ред. текста, вступ. ст., коммент. А. Н. Бернштама и Н. В. Кюнера. - М.; Л.: Изд-во АН CCCP, 1950. - LXXXVI. - 384 с.

Владимириов Б. Я. Сравнительная грамматика монгольского письменного языка и халхаского наречия. Введение и фонетика / Б. Я. Владимирцов. - М.; Л.: Изд-во Вост. ин-та, 1929. - XII. - 436 c.

Древнетюркский словарь / под ред. В. М. Наделяева, Д. М. Насилова, Э. Р. Тенишева, А. М. Щербака. - Л.: Наука, 1969. - XXXVIII. - 714 с.

Зуев Ю. А. Древнетюркская социальная терминология в китайском тексте VIII в. / Ю. А. Зуев // Вопросы археологии Казахстана. Вып. 2 / отв. ред. 3. Самашев. - Алматы; М.: Ғылым, 1998.

Зуев Ю. А. Ранние тюрки: очерки истории и идеологии / Ю. А. Зуев. - Алматы: ДайкПресс, 2002. -338 c.

Кубатин A. B. Система титулов в Тюркском каганате: генезис и преемственность / А. В. Кубатин. - Ташкент: Yangi nashr, 2016. - 192 с.

Кюнер Н. В. Китайские известия о народах Южной Сибири, Центральной Азии и Дальнего Востока / Н. В. Кюнер. - М.: Наука, 1961. - 391 с.

Маоцай Лю. Сведения о древних тюрках в средневековых китайских источниках / Лю Маоцай / пер. В. Н. Добжанского и Л. Н. Ермоленко // Бюллетень (Newsletter) общества востоковедов. Прил. 1. - М.: Изд-во ИВ РАН, 2002. - 126 с.

Материалы по истории сюнну (по материалам китайских источников) / предисл., пер. и примеч. В. С. Таскина. Вып. 1. - М.: Наука, 1968. - 283 с.

Севортян Э. В. Этимологический словарь тюркских языков (Общетюркские и межтюркские основы на гласные) / Э. В. Севортян. - М.: Наука, 1974. - 767 с.

Севортян Э. В. Этимологический словарь тюркских языков. Общетюркские и межтюркские основы на букву Б / Э. В. Севортян. - М.: Наука, 1978. - 349 с.

Сравнительно-историческая грамматика тюркских языков. Лексика. - М.: Наука, 1997. 800 с.; 2-е изд., доп. - М.: Наука, 2001. - 822 с.

Цэнь Чжун-мянь 岑仲勉. Ту-цзюэ цзи ши 突厥集史 / Цэнь Чжун-мянь 岑仲勉. - Пекин 北京: Чжун-хуа шу-цзу 中華書局, 1958. - 1136 с.

Bailey H.W. Dictionary of Khotan Saka / H. W. Bailey. - Cambridge: Cambridge University Press, 1979. - xvii, 559 p. 
[Boodberg P. A.] Selected Works of Peter A. Boodberg / P. A. Boodberg; compl. by A. P. Cohen. - Berkeley; Los Angeles; London: University of California Press, 1979. - xix, 502 p.

Clauson G. An Etymological Dictionary of Pre-Thirteenth-Century Turkish / G. Clauson. Oxford: Clarendon Press, 1972. - xlviii, 989 p.

Doerfer G. Türkische und mongolische Elemente im Neupersischen unter besonderer Berücksichtigung älterer neupersischer Geschichtsquellen vor allem der Mongolen- und Timuridenzeit / G. Doerfer. Bd. II. Türkische Elemente im Neupersischen. - Wiesbaden: Franz Steiner Verlag, 1965. - V, 671 s. (Akademie der Wissenschaften und der Literatur: Veröffentlichungen der Orientalischen Komission. - Bd. XIX).

Drompp M. R. Supernumerary Sovereigns: Superfluity and Mutability in the Elite Power Structure of the Early Türks (Tujue) / M. R. Drompp // Rulers from the Steppe: State Formation on the Eurasian Periphery. - Los Angeles: University of Southern California Ethnographics Press, 1991 P. 92-115, 350-352. (Proceedings of the Soviet-American Academic Symposia in Conjuction with the Museum Exhibitions "Nomads: Masters of the Eurasian Steppe". - Vol. 2).

Ecsedy H. Trade and War Relations between the Turks and China in the Second Half of the $6^{\text {th }}$ Century / H. Ecsedy // Acta Orientalia Academiae Scientiarum Hungaricae. - 1968. - Vol. XXXI. Fasc. 2. - P. 131-180.

Erdal M. Old Turkic Word Formation: A Functional Approach to the Lexicon / M. Erdal. Vol. I-II. Wiesbaben: Harrassowitz, 1991. - XIV, 874 p. (Turcologica. - Bd. 7).

Erdal M. A Grammar of Old Turkic / M. Erdal. - Leiden; Boston: Brill, 2004. - xii, 575 p. (Handbook of Oriental Studies, Section 8 Uralic \& Central Asia. - Vol. 3).

Erdal M. Helitbär and some other early Turkic names and titles / M. Erdal // Turkic Languages. - 2016. - No 20. - P. 170-178.

Erkoç H. $\dot{I}$. General Li Jing'in Askerî Düşüncesi ve Doğu Göktürk Kağanlığı'nın Çöküşü: Hacettepe Üniversitesi, Sosyal Bilimler Enstitüsü, Basılmamış / H. İ. Erkoç. - Ankara, 2015. - xiv, $280 \mathrm{~s}$.

Erkoç H. I. Batı Göktürk Kağanlığı'nın Kuruluşu / H. İ. Erkoç // Hacettepe Üniversitesi Edebiyat Fakültesi Dergisi. - 2016. - Cilt 33. - Sayı 1. - S. 43-72.

Hirth F. Über die chinesischen Quellen zur Kenntnis Centralasiens unter der Herrschaft der Sassaniden etwa in der Zeit 500-650 / F. Hirth // Wiener Zeitschrift für die Kunde des Morgenlandes. $-1896 .-$ Bd. X. - S. 225-241.

Hirth F. Nachworte zur Inschrift des Tonjukuk. Beiträge zur Geschichte der Ost-Türken im 7. und 8. Jahrhundert nach chinesischen Quellen / F. Hirth // Radloff W. Die alttürkischen Inschriften der Mongolei. Zweite Folge. - St. Petersburg: Kaiserliche Akademie der Wissenschaften, 1899. S. $1-140$.

Janhunen J. Proto-Mongolic // Mongolic languages / ed. by J. Janhunen. - London: Routledge, 2003. - P. 1-29.

Kasai Yukiyo. Die alttürkischen Wörter aus Natur und Gesellschaft in chinesischen Quellen (6. und 9. Jh.). Der Ausgangsterminus der chinesischen Transkription tū jué 突厥 / Kasai Yukiyo // "Die Wunder der Schöpfung". Mensch und Natur in der türksprachigen Welt / Hgs. B. Heuer, B. Kellner-Heinkele, C. Schönig. - Würzburg: Ergon-Verlag, 2012. - S. 81-141. (Istanbuler Texte und Studien. - Bd. 9).

Kasai Yukiyo. The Chinese Phonetic Transcriptions of Old Turkish Words in the Chinese Sources from $6^{\text {th }}-9^{\text {th }}$ Century: Focused on the Original Word Transcribed as tū jue 突厥 / Kasai Yukiyo // 内陸アジア言語の研究 [Nairiku ajia gengo no kenkyū] / Studies on the Inner Asian languages. 2014. - Vol. XXIX. - P. 57-135.

Казакстан тарихы туралы кытай деректемелері. IV том. Эулеттік тарихи жылнамалар. 2-бөлім / Кытай дерекмелерин аударган, түсіндірмелері мен ескертулерін жазган Б. Еженханұлы, Ж. Ошан. - Алматы: Дайк-Пресс, 2006. - 480 б.

Klaproth J. Memoire sur l'identité des Thou khiu et des Hioung nou avec les / J. Klaproth // Journal Asiatique. - 1827. - Vol. VII. - P. 257-268.

Liu Mau-tsai. Die chinesischen Nachrichten zur Geschichte der Ost-Türken (T'u-küe) / Liu Mau-tsai. - Wiesbaden: Otto Harrassowitz, 1958. - I. Buch. Texte. - 484 s. (Göttinger asiatische Forschungen: Monographienreihe zur Geschichte, Sprache u. Literatur d. Völker Süd-, Ost- u. Zentralasiens. - Bd. 10). 
Liu Mau-tsai. Die chinesischen Nachrichten zur Geschichte der Ost-Türken (T’u-küe) / Liu Mau-tsai. - Wiesbaden: Otto Harrassowitz, 1958. - II. Buch. Anmerkungen, Anhänge, Index. S. 485-831 (Göttinger asiatische Forschungen: Monographienreihe zur Geschichte, Sprache u. Literatur d. Völker Süd-, Ost-u. Zentralasiens. - Bd. 10).

Marquart J. Die Chronologie Der Alttürkischen Inschriften / J. Marqaurt mit einem Vorwort und Anhang von Prof. W. Bang in Löwen. - Leipzig: Dieterichsche Verlags-Bucchandlung, 1898. VII, $112 \mathrm{~s}$.

Parker E. H. The Early Turks - Part IV (From the T'ang Shu; Continued from where it leaves off at Part I) / E. H. Parker // The China Review. - 1901. - Vol. 25. - No 5. - P. 234-247.

Parker E. H. A thousand years of the Tartars / E. H. Parker. $-2^{\text {nd }}$ ed., rev. and reset. - New York: A. A. Knopf, inc., 1924. - 4 p. 1., [xi]-xii p., 2 1., 288 p.

Pelliot P. Tokharien et koutchéen / P. Pelliot // Journal Asiatique. - 1934. - Vol. CCXXIV. P. 23-106.

Pritsak O. Die bulgarische Fürstenliste und die Sprache der Protobulgaren / O. Pritsak. - Wiesbaden: Otto Harrassöwitz, 1955. - 101, 3 s.

Pulleyblank E. G. A Lexicon of Reconstructed Pronunciation in Early Middle Chinese, Late Middle Chinese, and Early Mandarin / E. G. Pulleyblank. - Vancouver: UBC Press, 1991. - vii, $488 \mathrm{p}$.

Róna-Tas A. The Reconstruction of Proto-Turkic and the Genetic Question / A. Róna-Tas // The Turkic Languages / eds. L. Johanson \& E. A. Csato. - London; New York: Routledge, 1998. P. $67-80$.

Róna-Tas A. Bayan and Asparux. Nine Notes on Turks and Iranians in East Europe / A. RónaTas // Turks and Iranians. Interactions in Language and History / ed. by É. Á. Csató, L. Johanson, A. Róna-Tas, B. Utas. - Wiesbaden: Harrassowitz Verlag, 2016. - P. 65-78 (Turcologica. - Bd. 105).

Starostin S. A. An Etymological Dictionary of Altaic Languages / S. A. Starostin, A. V. Dybo, O. A. Mudrak. Pt. I. A - K. - Leiden; Boston: Brill, 2003. - P. 1-858 (Handbook of Oriental Studies. Section eight, Central Asia. - Vol. 8/1).

Stein R. [Rev.] Houa-si Hie-ho ta-hio Tchong-kouo wen houa yen-kieou-souo tsi-k'an 寒西雄合大學, 中國灾化研究所集刊 (Studia Serica, Journal of the Chinese Cultural Studies Research Institute, West China Union University), Vol. I. Parts 1, 2, 3, Chengtu, sept. 1940, dec. 1940 et mars 1941 / R. Stein // Bulletin de l'École française d'Extrême-Orient. - 1941.-Vol. 41.No. 2. - P. 406-441.

Taşağıl A. Gök-Türkler II (fetret devri 630-681) / A. Taşağıl. - Ankara: Türk Tarih Kurumu, 1999. - viii, 128, [12] s. (Türk Tarih Kurumu Yayınları. - VII. Dizi - Say1 160ª).

Taşağıl A. Gök-Türkler I / A. Taşağıl. - 2. baskı. - Ankara: Türk Tarih Kurumu, 2003. - ix, 197, [23] s. (Türk Tarih Kurumu Yayınlar1. - VII. Dizi - Say1 160²).

Visdelou C. Histoire de la Tartarie / C. Visdelou // Bibliothèque orientale: ou Dictionnaire universel contenant tout ce qui fait connoître les peuples de l'Orient. Leurs histories et traditions tant fabuleuses que véritables. Leurs religions et leurs sectes. Leurs gouvernemens, politique, loix, moeurs, coûtumes, et les révolutions de leurs empires. Les arts et les sciences ... Les vies de leurs saints, philosophes, docteurs, poëtes, historiens, capitaines, \& de tous ceux qui se sont rendus illustres par leur vertu, leur sçavoir ou leurs actions. Des jugemens critiques et des extraits de leurs livres, écrits en arabe, persan ou turc sur toutes sortes de matières \& de professions, par Mr. d'Herbelot. T. IV. - La Haye: J. Neaulme \& N. van Daalen, 1779. - P. 46-249.

\section{References}

Bichurin N. YA. [Iakinf]. Sobranie svedenij o narodah, obitavshih v Srednej Azii v drevnie vremena T. I / N. Ya. Bichurin [Iakinf]; red. teksta, vstup. st., komment. A. N. Bernshtama i N. V. Kyunera.. - M.; L.: Izd-vo AN SSSR, 1950. - LXXXVI. - 384 s.

Vladimircov B. Ya. Sravnitel'naya grammatika mongol'skogo pis'mennogo yazyka i halhaskogo narechiya. Vvedenie i fonetika / B. Ya. Vladimircov. - M.; L.: Izd-vo Vost. in-ta, 1929. - XII. - 436 s.

Drevnetyurkskij slovar' / pod red. V. M. Nadelyaeva, D. M. Nasilova, E. R. Tenisheva, A. M. Shcherbaka. - L.: Nauka, 1969. - XXXVIII. - 714 s. 
Zuev Yu. A. Drevnetyurkskaya social'naya terminologiya v kitajskom tekste VIII v. / Yu. A. Zuev // Voprosy arheologii Kazahstana. Vyp. 2; otv. red. Z. Samashev. - Almaty; M.: Fylym, 1998.

Zuev Yu. A. Rannie tyurki: ocherki istorii i ideologii / Yu. A. Zuev. - Almaty: Dajk-Press, 2002. $-338 \mathrm{~s}$.

Kubatin A. V. Sistema titulov v Tyurkskom kaganate: genezis i preemstvennost' / A. V. Kubatin. - Tashkent: Yangi nashr, 2016. - 192 s.

Kyuner N. V. Kitajskie izvestiya o narodah Yuzhnoj Sibiri, Central'noj Azii i Dal'nego Vostoka / N. V. Kyuner. - M.: Nauka, 1961. - 391 s.

Maocaj Lyu. Svedeniya o drevnih tyurkah v srednevekovyh kitajskih istochnikah / Lyu Maocaj / per. V. N. Dobzhanskogo i L. N. Ermolenko // Byulleten’ (Newsletter) obshchestva vostokovedov. Pril. 1. - M.: Izd-vo IV RAN, 2002. - 126 s.

Materialy po istorii syunnu (po materialam kitajskih istochnikov) / predisl., per. i primech. V. S. Taskina. Vyp. 1. - M.: Nauka, 1968. - 283 s.

Sevortyan E. V. Etimologicheskij slovar' tyurkskih yazykov (Obshchetyurkskie i mezhtyurkskie osnovy na glasnye) / E. V. Sevortyan. - M.: Nauka, 1974. - 767 s.

Sevortyan E. V. Etimologicheskij slovar' tyurkskih yazykov. Obshchetyurkskie i mezhtyurkskie osnovy na bukvu B / E. V. Sevortyan. - M.: Nauka, 1978. - 349 s.

Sravnitel'no-istoricheskaya grammatika tyurkskih yazykov. Leksika. - M.: Nauka, 1997. 800 s.; 2-e izd., dop. - M.: Nauka, 2001. - 822 s.

Cen' Chzhun-myan' 岑仲勉. Tu-czyue czi shi 突厥集史 / Cen' Chzhun-myan' 岑仲勉. - Pekin 北: Chzhun-hua shu-czu 中華書局, 1958. - 1136 s.

Bailey H. W. Dictionary of Khotan Saka / H. W. Bailey. - Cambridge: Cambridge University Press, 1979. - xvii, 559 p.

[Boodberg P. A.] Selected Works of Peter A. Boodberg / P. A. Boodberg; compl. by A. P. Cohen. - Berkeley; Los Angeles; London: University of California Press, 1979. - xix, 502 p.

Slauson G. An Etymological Dictionary of Pre-Thirteenth-Century Turkish / G. Clauson. Oxford: Clarendon Press, 1972. - xlviii, 989 p.

Doerfer $G$. Türkische und mongolische Elemente im Neupersischen unter besonderer Berücksichtigung älterer neupersischer Geschichtsquellen vor allem der Mongolen- und Timuridenzeit / G. Doerfer. Bd. II. Türkische Elemente im Neupersischen. - Wiesbaden: Franz Steiner Verlag, 1965. - V, 671 s. (Akademie der Wissenschaften und der Literatur: Veröffentlichungen der Orientalischen Komission. - Bd. XIX).

Drompp M. R. Supernumerary Sovereigns: Superfluity and Mutability in the Elite Power Structure of the Early Türks (Tujue) / M. R. Drompp // Rulers from the Steppe: State Formation on the Eurasian Periphery. - Los Angeles: University of Southern California Ethnographics Press, 1991 P. 92-115, 350-352. - (Proceedings of the Soviet-American Academic Symposia in Conjuction with the Museum Exhibitions "Nomads: Masters of the Eurasian Steppe". - Vol. 2).

Ecsedy $H$. Trade and War Relations between the Turks and China in the Second Half of the $6^{\text {th }}$ Century / H. Ecsedy // Acta Orientalia Academiae Scientiarum Hungaricae. - 1968. - Vol. XXXI. Fasc. 2. - P. 131-180.

Erdal M. Old Turkic Word Formation: A Functional Approach to the Lexicon / M. Erdal. Vol. I-II. Wiesbaben: Harrassowitz, 1991. - XIV, 874 p. (Turcologica. - Bd. 7).

Erdal M. A Grammar of Old Turkic / M. Erdal. - Leiden; Boston: Brill, 2004. - xii, 575 p. (Handbook of Oriental Studies, Section 8 Uralic \& Central Asia. - Vol. 3).

Erdal M. Helitbär and some other early Turkic names and titles / M. Erdal // Turkic Languages. - 2016. - No 20. - P. 170-178.

Erkoç H. I. General Li Jing'in Askerî Düşüncesi ve Doğu Göktürk Kağanlığı'nın Çöküşü: Hacettepe Üniversitesi, Sosyal Bilimler Enstitüsü, Basılmamış / H. İ. Erkoç. - Ankara, 2015. - xiv, $280 \mathrm{~s}$.

Erkoç H. I. Batı Göktürk Kağanlığı'nın Kuruluşu / H. İ. Erkoç // Hacettepe Üniversitesi Edebiyat Fakültesi Dergisi. - 2016. - Cilt 33. - Say1 1. - S. 43-72.

Hirth F. Über die chinesischen Quellen zur Kenntnis Centralasiens unter der Herrschaft der Sassaniden etwa in der Zeit 500-650 / F. Hirth // Wiener Zeitschrift für die Kunde des Morgenlandes. $-1896 .-$ Bd. X. - S. 225-241. 
Всемирная история

Hirth F. Nachworte zur Inschrift des Tonjukuk. Beiträge zur Geschichte der Ost-Türken im 7. und 8. Jahrhundert nach chinesischen Quellen / F. Hirth // Radloff W. Die alttürkischen Inschriften der Mongolei. Zweite Folge. - St. Petersburg: Kaiserliche Akademie der Wissenschaften, 1899. S. $1-140$.

Janhunen J. Proto-Mongolic // Mongolic languages / ed. by J. Janhunen. - London: Routledge, 2003. - P. 1-29.

Kasai Yukiyo. Die alttürkischen Wörter aus Natur und Gesellschaft in chinesischen Quellen (6. und 9. Jh.). Der Ausgangsterminus der chinesischen Transkription tū jué 突厥 / Kasai Yukiyo // "Die Wunder der Schöpfung". Mensch und Natur in der türksprachigen Welt / Hgs. B. Heuer, B. Kellner-Heinkele, C. Schönig. - Würzburg: Ergon-Verlag, 2012. - S. 81-141. (Istanbuler Texte und Studien. - Bd. 9).

Kasai Yukiyo. The Chinese Phonetic Transcriptions of Old Turkish Words in the Chinese Sources from $6^{\text {th }}-9^{\text {th }}$ Century: Focused on the Original Word Transcribed as tū jue 突厥 / Kasai Yukiyo // 内陸アジア言語の研究 [Nairiku ajia gengo no kenkyū] / Studies on the Inner Asian languages. 2014. - Vol. XXIX. - P. 57-135.

Казакстан тарихы туралы кытай деректемелері. IV том. Эулеттік тарихи жылнамалар. 2-болім / Кытай дерекмелерин аударган, тусіндірмелері мен ескертулерін жазган Б. Еженханұлы, Ж. Ошан. - Алматы: Дайк-Пресс, 2006. - 480 б.

Klaproth J. Memoire sur l'identité des Thou khiu et des Hioung nou avec les / J. Klaproth // Journal Asiatique. - 1827. - Vol. VII. - P. 257-268.

Liu Mau-tsai. Die chinesischen Nachrichten zur Geschichte der Ost-Türken (T'u-küe) / Liu Mau-tsai. - Wiesbaden: Otto Harrassowitz, 1958. - I. Buch. Texte. - 484 s. (Göttinger asiatische Forschungen: Monographienreihe zur Geschichte, Sprache u. Literatur d. Völker Süd-, Ost- u. Zentralasiens. - Bd. 10).

Liu Mau-tsai. Die chinesischen Nachrichten zur Geschichte der Ost-Türken (T'u-küe) / Liu Mau-tsai. - Wiesbaden: Otto Harrassowitz, 1958. - II. Buch. Anmerkungen, Anhänge, Index. S. 485-831 (Göttinger asiatische Forschungen: Monographienreihe zur Geschichte, Sprache u. Literatur d. Völker Süd-, Ost-u. Zentralasiens. - Bd. 10).

Marquart J. Die Chronologie Der Alttürkischen Inschriften / J. Marqaurt mit einem Vorwort und Anhang von Prof. W. Bang in Löwen. - Leipzig: Dieterichsche Verlags-Bucchandlung, 1898. - VII, $112 \mathrm{~s}$.

Parker E. H. The Early Turks - Part IV (From the T'ang Shu; Continued from where it leaves off at Part I) / E. H. Parker // The China Review. - 1901. - Vol. 25. - No 5. - P. 234-247.

Parker E. H. A thousand years of the Tartars / E. H. Parker. $-2^{\text {nd }}$ ed., rev. and reset. - New York: A. A. Knopf, inc., 1924. - 4 p. 1., [xi]-xii p., 2 1., 288 p.

Pelliot P. Tokharien et koutchéen / P. Pelliot // Journal Asiatique. - 1934. - Vol. CCXXIV. P. 23-106.

Pritsak O. Die bulgarische Fürstenliste und die Sprache der Protobulgaren / O. Pritsak. - Wiesbaden: Otto Harrassöwitz, 1955. - 101, 3 s.

Pulleyblank E. G. A Lexicon of Reconstructed Pronunciation in Early Middle Chinese, Late Middle Chinese, and Early Mandarin / E. G. Pulleyblank. - Vancouver: UBC Press, 1991. - vii, $488 \mathrm{p}$.

Róna-Tas A. The Reconstruction of Proto-Turkic and the Genetic Question / A. Róna-Tas // The Turkic Languages / eds. L. Johanson \& E. A. Csato. - London; New York: Routledge, 1998. P. $67-80$.

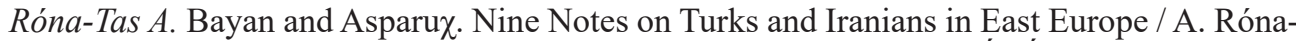
Tas // Turks and Iranians. Interactions in Language and History / ed. by É. Á. Csató, L. Johanson, A. Róna-Tas, B. Utas. - Wiesbaden: Harrassowitz Verlag, 2016. - P. 65-78 (Turcologica. Bd. 105).

Starostin S. A. An Etymological Dictionary of Altaic Languages / S. A. Starostin, A. V. Dybo, O. A. Mudrak. Pt. I. A - K. - Leiden; Boston: Brill, 2003. - P. 1-858 (Handbook of Oriental Studies. Section eight, Central Asia. - Vol. 8/1).

Stein R. [Rev.] Houa-si Hie-ho ta-hio Tchong-kouo wen houa yen-kieou-souo tsi-k'an 寒西雄 合大學, 中國灾化研究所集刊 (Studia Serica, Journal of the Chinese Cultural Studies Research 
Institute, West China Union University), Vol. I. Parts 1, 2, 3. Chengtu, sept. 1940, dec. 1940 et mars 1941 / R. Stein // Bulletin de l'École française d'Extrême-Orient. - 1941. - Vol. 41. - No. 2. P. 406-441.

Taşağll A. Gök-Türkler II (fetret devri 630-681) / A. Taşağıl. - Ankara: Türk Tarih Kurumu, 1999. - viii, 128, [12] s. (Türk Tarih Kurumu Yayınları. - VII. Dizi - Sayı 160a).

Taşağıl A. Gök-Türkler I / A. Taşağıl. - 2. bask1. - Ankara: Türk Tarih Kurumu, 2003. - ix, 197, [23] s. (Türk Tarih Kurumu Yayınları. - VII. Dizi - Say1 1601)

Visdelou C. Histoire de la Tartarie / C. Visdelou // Bibliothèque orientale: ou Dictionnaire universel contenant tout ce qui fait connoître les peuples de l'Orient. Leurs histories et traditions tant fabuleuses que véritables. Leurs religions et leurs sectes. Leurs gouvernemens, politique, loix, moeurs, coûtumes, et les révolutions de leurs empires. Les arts et les sciences ... Les vies de leurs saints, philosophes, docteurs, poëtes, historiens, capitaines, \& de tous ceux qui se sont rendus illustres par leur vertu, leur sçavoir ou leurs actions. Des jugemens critiques et des extraits de leurs livres, écrits en arabe, persan ou turc sur toutes sortes de matières \& de professions, par Mr. d'Herbelot. T. IV. - La Haye: J. Neaulme \& N. van Daalen, 1779. - P. 46-249. 